\title{
RESTRICTIONS OF PRIVATE PROPERTY RIGHT \\ IN TERMS OF THE COVID-19 PANDEMIC: \\ THE EXPERIENCE OF THE US, UK AND UKRAINE
}

\author{
KATERYNA NEKIT*
}

\begin{abstract}
The COVID-19 pandemic has had a significant impact on human rights. Many rights have been restricted to prevent the spread of infection. The restrictions on private property rights during the pandemic were not so obvious, but no less significant. The massive closure of restaurants, cafes, cinemas and other crowded places has resulted in significant losses for business owners. The question arose about the admissibility of such restrictions on the rights of owners, as well as the need to compensate for the losses caused. The purpose of this article is to study the criteria developed by international practice under which the restriction of property rights is allowed, and approaches to resolving issues of compensation for losses caused to owners when it is necessary to ensure a balance of private and public interests in Ukraine. The article also analyzes approaches to resolving issues of compensation for losses caused to owners as a result of restrictions on their rights, developed in the case law of the United States and Great Britain.
\end{abstract}

Keywords: private property, human rights, pandemic COVID-19, restrictions, compensation.

Summary: 1. Introduction. 2. General Remarks on The Limits and Restrictions of Property Rights. 3. The Concept of Property in The Case Law of The European Court of Human Rights and The Admissibility of Interference in The Peaceful Possession of Property. 4. Regarding The Possibility of Compensating The Owners For The Losses Incurred During The Quarantine Introduced Because of The Covid-19 PAndemic. 4.1. Resolving the issue of compensation for the seizure of private property in the US practice. 4.2. Features of ensuring the protection of private property from state interference in British law. 4.3. The problem of payment of compensation to owners for losses incurred during quarantine in the Ukrainian reality. 5. CONCLUSIONS.

\section{INTRODUCTION.}

The absolute nature of the property right does not exclude the possibility of its restrictions, in case it is required by the interests of the state or society. The organic connection between property rights and its restrictions (the relationship between rule (freedom) and exceptions) is a key aspect of property relations as a legal institution capable of ensuring the effective development of a market economy (Mattey \& Sukhanov, 1999). The possibility of restricting the right to private property in the interests of society is provided both at the international level - by the Protocol № 1 to the European Convention for the Protection of Human Rights and Fundamental Freedoms of 1950 (hereinafter referred to as the Convention) and nationally - by the Constitution of Ukraine (Article 41). These regulations give rise to restrictive measures on owners' rights in response to the

\footnotetext{
* PhD, Associate Professor of Civil Law Department of National University "Odessa Law Academy", Odessa, Ukraine, ORCID: 0000-0002-3540-350X (katerinanekit@gmail.com)
} 
threat posed by the spread of the COVID-19 pandemic. For example, during the pandemic and the quarantine imposed to prevent large crowds, numerous restaurants and cafes, shops and malls, entertainment venues and cinemas, were closed, public transport was banned, many flights were cancelled etc. It is obvious that such measures have resulted not only in a negative impact on the economy, but also in causing significant losses in the form of lost profits for the owners of such institutions, as well as their suppliers.

Such restrictive measures may be considered as an impact on property rights in accordance with Art. 1 of Protocol № 1 to the Convention in the sense of expropriation, control over the use or interference with the peaceful possession of property. This is a manifestation of the imposition of restrictions in the public interest, as health measures are considered to serve a legitimate purpose (McBride, 2020). However, the question arises as to in what cases and to what extent the right of private property may be restricted in the event of public danger and whether the owners have the right to proper compensation for the established restrictions.

\section{General Remarks on The Limits and Restrictions of Property Rights.}

The category of limits and restrictions in some sources is revealed through the concept of incentives in law. The positive vector of their influence is manifested in legal norms that encourage social relations necessary for society and the state (Vedyakhin, 1992). Incentives are provided through restrictions in the broadest sense of the word. Restraining legal incentives can be considered as: 1) legal restrictions on illegal activities, that create conditions for subjects and public interests for protection and defense; 2) established by the law limits within which the subjects must act; 3 ) exceptions to certain opportunities in the activities of entities (Porotikova, 2007).

In the science of civil law, the question of the relationship between the concepts of restrictions and encumbrances in law, as well as the concepts of "restrictions" and "limits" of the exercise of subjective property rights remains debatable. Quite often the concepts of limitations and boundaries are identified. In particular, professor K. Pobedonostsev defined restrictions as a negative part of property rights, while he equated limits and restrictions in legal significance, form and consequences (Pobedonostsev, 2003). S. Scryabin noted that the restriction of property rights should be understood as the limits of the exercise of subjective property rights to an individually determined thing, based on certain prohibitions that were previously established by positive law or were related to the rights of others to the same thing (Scryabin, 2006). The same position was held by professor D. Meyer, who did not distinguish between the concepts of "restriction", "encumbrance" and "limits" of property rights (Meyer, 2003).

However, scholars often point to the need to distinguish between the concepts of restrictions and encumbrances on property rights. It is stated that restrictions are a framework that cannot be exceeded in the exercise of their subjective right, they are defined by law and are inherent in all civil rights, not only property rights (Aguiar Ribeiro Do Nascimento, 2018). At the same time, encumbrances are additional restrictions on the rights imposed on the owner or other holder of property rights in accordance with the 
contract or a more specific article of law. Thus, restrictions are always objective because they do not depend on the will of the owner or others, but are determined by law, while encumbrances are subjective because they depend on the lawful will of the subjects or the court (Niyazova, 2016).

Regarding the correlation between limits and restrictions, it is also noted that limits can be defined as the delineation of the area in which the owner has full dominance over the property belonging to him, they determine the range of rights that the owner has. Restrictions, on the contrary, to some extent oppress, restrain the owner (Alexandrina, 2002). In turn, restrictions and encumbrances are defined as certain oppressions within the limits of the exercise of property rights. However, the difference between them is that encumbrances can be imposed on the property (such as easements), while restrictions are only certain encroachments on rights. Although both restrictions and encumbrances on property rights have almost the same features: 1) established within the limits of the exercise of property rights; 2) associated with certain adverse conditions; 3) entail a reduction in the scope of the owner's capabilities in the exercise of his property rights; 4) aimed at protecting public relations (Shvedkova, 2004).

It seems appropriate to distinguish between the concepts of restrictions and encumbrances of property rights, based on whether such frameworks established for the owner in the exercise of his right is general and defined by the public interest (restriction), or is a special case determined by individual interest, based on special legal provisions or the will of the owner (encumbrance).

\section{The Concept of Property in The Case Law of The European Court of Human Rights and The Admissibility of Interference in The Peaceful Possession of Property.}

In order to understand whether the owners, whose rights were restricted during the pandemic by depriving them of the opportunity to use their property in business, have the right to compensation, it is necessary to mention the meaning of "property" used today in the case law of the European Court of Human Rights (hereinafter reffered to as ECtHR).

It is well known, that the Protocol № 1 to the Convention uses the term “possessions", which in its essence is understood more broadly than the term "property", which is used in Ukrainian legislation. It has been repeatedly pointed out that the category "property" within the meaning of the Protocol № 1 to the Convention has "an autonomous meaning which does not depend on formal classifications in national law" (Karnaukh, 2016). Not only physical goods, but also some rights and interests that make up assets can also be considered as "property". In addition, the subject of protection may be not only existing property, but also the so-called "legitimate expectations". In particular, the Court includes, in addition to movable and immovable property, property and non-property interests, such as claims and debts by courtorder, company shares and otherfinancial instruments, business licenses, future income, intellectual property, real estate and residential leases, social benefits and pensions, professional clients, etc. (Council of Europe / European Court of Human Rights, 2019). 
Thus, future income within the meaning given by the ECtHR should also be considered a type of property, so depriving owners of the opportunity to receive income can to some extent be considered as confiscation of property. At the same time, in accordance with Art. 41 of the Constitution of Ukraine, compulsory alienation of objects of private property can be used only as an exception for reasons of public necessity, on the basis and in the manner prescribed by law, and subject to prior and full reimbursement of their value. The logical question is whether such restrictions on the rights of owners were permissible during the quarantine, and whether the state should not compensate the owners for the income they lost as a result of the quarantine. To find an answer to this question, we will analyze the conditions under which state interference in the peaceful possession of property is allowed, as well as the conditions under which human rights, including property rights, may be restricted in extraordinary circumstances, including the COVID-19 pandemic.

In the practice of the ECtHR, an approach has been developed, according to which there are three main conditions for state intervention in the peaceful possession of property. First, it is legality, i.e. it is verified whether such a measure is provided by national law. Secondly, it is the pursuit of the public interest during the intervention. Third, it is proportionality, i.e. ensuring a fair balance between the public interest and the interests of individuals suffering from such interference.

Criteria for assessing the validity of state intervention in the right of a person to peaceful possession of property, in accordance with the case law of the ECtHR, are:

1) the object of legal protection should be qualified as property within the meaning of Art. 1 of Protocol № 1 to the Convention;

2) types of intervention should be defined in the Convention norm;

3) the existence of a legitimate purpose, taking into account the public interest;

4) the proportionality of such intervention and the existence of a fair balance between the requirements of the general interest of society and the requirements of protection of fundamental human rights;

5) compliance of such interference with the criterion of legal certainty or legality (in the absence of legitimate grounds for interference, it cannot meet the requirements of Article 1 of Protocol № 1 to the Convention) (Belyanevich, 2016).

In addition to this approach developed over the years by the ECtHR, the United Nations guidelines for restricting human rights in the context of the COVID-19 pandemic need to be taken into account. They stated that restrictions on rights are allowed under the following conditions:

1) legality - the restriction must be introduced by law. This means that the restriction must be enshrined in the national law of general application in force at the time the restriction is applied. Such a law should not be arbitrary or unreasonable, it should be clear and accessible to the public; 
2) necessity - restrictions must be necessary to protect one of the permissible grounds specified in the International Covenant on Civil and Political Rights, which includes health care, and must meet an urgent social need;

3) proportionality - restrictions must be proportionate to the interests, i.e. they must correspond to the achievement of their protective function; and this should be the least intrusive option among those that can help achieve the desired result;

4) non-discrimination - no restriction may discriminate, which is contrary to international human rights law (Demir, 2017);

5) all restrictions should be interpreted directly and in favor of the relevant law. No restriction may be applied arbitrarily;

6) the government bears the burden of justifying restrictions on rights (United Nations, 2020).

Thus, the restriction of the rights of owners, in particular by temporarily depriving them of the opportunity to use their property in business and receive income from its use, could be allowed only if all these requirements are met.

\section{Regarding The Possibility of Compensating The Owners For The Losses Incurred During The Quarantine Introduced Because of The Covid-19 Pandemic.}

\subsection{Resolving the issue of compensation for the seizure of private property in the US practice.}

The prohibition of confiscation of private property without proper compensation is enshrined in the US law, where, under the Fifth Amendment, private property cannot be confiscated for public use without fair compensation. The purpose of such a provision is to deter the state from forcing individuals to carry public needs, which, based on the understanding of justice, should be borne by society as a whole (Tager, White \& Hamilton, 2020). In American law, there are two cases of "seizure" of private property.

The first case of seizure is, in fact, the physical seizure of property. When property is physically confiscated from a person, the state has a "categorical obligation" to reimburse the value of such property to the former owner. It does not matter whether such withdrawal was only partial or only temporary, nor does the reason for such withdrawal.

The second case, which can be considered as the seizure of property from the owner - is the establishment of a special procedure for regulating the use of property. In this case, in order to pay compensation, it is necessary to establish whether such regulation is so burdensome for the owner that it is practically equal to the seizure of property.

To answer this question, the US Supreme Court has developed two tests. Regulation can be seen as a seizure if it meets the "categorical test", namely when "all economic benefits" are excluded from the use of the property. However, more often the 
regulation falls under the "ad-hoc test". In this situation, the court examines three aspects of the normative act to decide whether there is a "seizure" of property that requires fair compensation. First, the court considers the "economic impact" of this regulation in the form of a fraction, the numerator of which is the value deducted from the property, and the denominator is the value of the property not encumbered by the regulation. In this fraction the denominator is key; the courts determine it in accordance with the entire property interest in question, and not only in relation to the part burdened with regulation (i.e. the entire land plot where the house is located, and not only the part of the plot that is restricted in use). Second, the court examines the extent to which a legal act impedes a reasonable "investment expectation" as to how a person can count on the use of his or her property. For example, a company that submits trade secret data to the regulator, knowing that the agency may disclose it publicly, has no reasonable expectation that the data will remain confidential. Third, the court carefully examines the "nature" of this regulation. Regulation, which can be equated with physical intrusion into property, will be interpreted as "seizure" rather than encumbering property as a result of a legislative scheme that "adjusts the benefits and burdens of economic life to promote the common good" (Stiff, 2020).

The so-called "rule of necessity" is also taken into account when deciding on compensation for the seizure of property. Thus, the US Supreme Court recognizes that emergencies such as war may require "strict regulation of almost all resources" to prevent the inevitable loss of life or property. Based on this, according to the "rule of necessity", if the state creates a fire station, destroying a person's house to save the homes of others, the state does not need to pay compensation to the owner whose property was sacrificed to the common good. Some scholars have drawn an analogy between a pandemic and a state of war in their analysis of how to respond to the restrictions imposed by COVID- 19 . Therefore, it is important to address the issue of compensation to owners for losses incurred in connection with hostilities. This issue is ambiguous in the US case law.

Thus, in the case of United States v. Central Eureka Mining, Co, the Court, citing the "war effect", refused to compensate private mine owners for closing them because workers at the mines were needed to work in the mines to extract the copper needed for hostilities. Although the Court recognized here the analogy of "seizure" of property, it noted that such restrictions, which led to losses on the part of private owners, were insignificant compared to the losses incurred by the whole society during the war (Stiff, 2020).

On the other hand, in some emergencies, the Court does not deny the possibility of compensating owners for the seizure of property for public interest. For example, in the case of Mitchell v. Harmony, the Court noted that the use of private property for public purposes is allowed, but subject to full compensation to the owner (Stiff, 2020).

Thus, in military matters, the Court has established two general rules: if the government destroys private property to avoid immediate loss of life or property, no seizure occurs and no compensation is paid. However, if the government confiscates property for emergency use, compensation is payable (Stiff, 2020). 
In the case of restrictions on the rights of owners in terms of the COVID-19 pandemic, in American practice, in order to answer the question of whether compensation is payable, it is also necessary to determine whether this situation falls under the "rule of necessity".

Assuming that the "rule of necessity" goes beyond the military context, the court is likely to apply it only to pandemic response measures labeled "actual emergency, imminent danger and actual necessity". And even then, the "rule of necessity" is likely to justify only the destruction of property, not its appropriation, on a temporary or permanent basis, in order to respond to the pandemic.

If the court finds the "rule of necessity" unsuitable, then the usual decision-making system is likely to apply. Seizure of private property for public use is likely to require compensation. It is doubtful that the state can seize private stocks of medical supplies to respond to a pandemic without paying fair compensation to the property owner. Therefore, if the state requires the use of private property to comply with quarantine or testing for COVID-19, it will most likely have to pay the owner.

However, if there is no physical seizure of property, pandemic responses will be considered in accordance with regulatory tests by the US Supreme Court. It is unlikely that the measures implemented in connection with COVID-19 would satisfy the "categorical test" of the Supreme Court, depriving the property owner of "all" economic types from the use of property (in one case the Supreme Court suggested that the reduction in property value by even $95 \%$ was insufficient to pay compensation). Therefore, it will be relevant for one of the most common responses to the pandemic - the order of states and local governments to close private businesses to promote social distancing. The closure order deprives the property owner of the right to do business during the closure period, but the order is unlikely to lead to a complete loss of value because, as the Court noted during the moratorium on property use, "the value of the property will be restored as soon as the ban is lifted. When a closure order allows a business to continue to operate in part (for example, to sell takeaway food), it can be said that the property owner retains use of the property during the temporary closure, thus reducing the chances of finding that the restrictions exclude "all" uses of property.

However, the inconsistency of the situation with the "categorical test" does not preclude the possibility of compensation for the imposed restrictions. In this case, the "ad hoc test" of the Supreme Court is likely to be used. Thus, some areas of business, such as a restaurant or a dentist's office, may not have reasonable expectations of continuing to serve customers in the midst of a pandemic. With this in mind, the federal and state governments may in some way mitigate the economic impact on the regulation of such entities (Stiff, 2020).

In the face of the economic challenges posed by the COVID-19 outbreak, the United States is also considering putting small business losses on insurers that cover business breaks, or the insurance industry as a whole (Tager, White \& Hamilton, 2020). However, in such a case, insurance companies may also apply the protection provided by 
the Constitution against imposing excessive burdens on them. In such cases, excessive insurance payments may also qualify as foreclosure. Although in this case it will be difficult for companies to prove that it is a seizure, as taxes and payments usually are not qualified as a seizure, it is likely that payments to the insurance fund will be qualified as a property interest subject to seizure rules (Tager, White \& Hamilton, 2020).

\subsection{Features of ensuring the protection of private property from state interference in British law.}

In the United Kingdom, similar principles are applied to ensure the protection of private property from interference by the state. English public law contains clear provisions prohibiting the confiscation of property or disproportionate interference with the use of property without adequate compensation for such acts. The principle of interpretation of the law in the UK is to prohibit the application of the law on the seizure of private property without compensation, unless the intention to do that is formulated clearly and unambiguously (In re Peacock (Secretary of State for the Home Department intervening); Colonial Sugar Refining v Melbourne Harbour Trust).

However, this is not an absolute limitation, and the state may apply legal provisions to restrict non-compensatory property rights (Hoveringham Gravels Ltd v Secretary of State for the Environment). The government may also impose restrictions on the use of property in the public interest by enacting general regulatory laws.

In addition, English courts also rely on the Human Rights Act 1998, which establishes the fundamental rights and freedoms to which everyone is entitled in the United Kingdom. It incorporates the rights set out in the Convention into domestic English law (Equality and Human Rights Comission, 1998).

It is this regulation that owners can rely on to seek compensation for the restriction of their rights during the COVID-19 pandemic. Such restrictions were introduced in the UK by the Coronavirus Act 2020, which allowed the government to ban the holding of events or gatherings, as well as the entry, exit or accommodation of persons to protect against the spread of COVID-19 or to promote the best deployment of medical or emergency resources. The Coronavirus Act 2020 does not provide for compensation when the government exercises such powers.

The government used this power to order the closure of a large number of businesses, including restaurants, bars, pubs and gyms. Since such measures have deprived many companies and individuals of income, they may try to argue that this means deprivation of property, not just control over its use, and therefore they should be entitled to compensation. Interested parties may rely on the above principle of interpretation of laws, in particular the Coronavirus Act 2020, which prohibits the application of the law on the seizure of private property without compensation, unless the intention to do so is formulated clearly and unambiguously. 
However, based on the Human Rights Act 1998, the court may well argue that the restrictions applied during the pandemic ensure a fair balance between the rights of the individual and society as a whole, especially since this balance can sometimes only be achieved when deprivation of property has taken place without compensation. This view is likely to be supported by the fact that, although the government does not fully compensate businesses for all the losses caused by the restrictions, it has announced a number of other measures to support them during this period.

In particular, in March 2020, the Chancellor announced measures to provide economic support to businesses in connection with the COVID-19 pandemic. The initial funding provided by the state and guaranteed loans to support the business amounted to 330 billion pounds. These loans were to be available to any business that needed access to cash to pay rent, wages, or suppliers, or to purchase shares. Support was provided through two schemes: to support large firms, a lending mechanism was agreed with the Bank of England to provide cheap and readily available commercial paper; to support lending to small and medium-sized businesses, the budget provided loans for business interruptions in the amount of up to 5 million pounds. At the same time, the government provided lenders with a guarantee of 80 percent for each loan. The government also had to cover the first six months of interest payments to each business that receives a loan.

In addition, the government has budgeted that retailers, hospitality and entertainment businesses worth less than $£ 51,000$ will not pay any rates for the next 12 months. In addition, it was stated that retailers, hospitality and entertainment businesses worth more than $£ 15,000$ but less than $£ 51,000$ would receive an additional cash grant of up to $£$ 25,000 per business. It was also announced that 700,000 of the smallest businesses (those eligible for small business benefits) would receive a cash grant of $£ 3,000$. This amount was later increased to $£ 10,000$.

In April 2020, the UK government introduced further financial support measures for businesses in the form of the Coronavirus Large Business Interruption Loan Scheme and amended the terms of the Coronavirus Business Interruption Loan Scheme.

\subsection{The problem of payment of compensation to owners for losses incurred during quarantine in the Ukrainian reality.}

According to the Ukrainian legislation, in the event of a pandemic, there are two possible types of losses that property owners may incur. First, a pandemic is a basis for requisitioning property if the public interest so requires. Thus, in accordance with Art. 353 of the Civil Code of Ukraine, in case of natural disaster, accident, epidemic, epizootic and other extraordinary circumstances, for public necessity property may be forcibly alienated from the owner on the basis and in the manner prescribed by law, subject to prior and full reimbursement of its value (requisition). In a state of war or emergency, property may be forcibly alienated from the owner, followed by full reimbursement of its value. Therefore, if private property is confiscated, such as medical equipment needed to help people in an emergency, or used, for example, motels to house temporarily isolated people infected 
with the coronavirus, owners will be entitled to claim reimbursement or payment for use of such property.

The question of the amount of such compensation is decided separately in each case, taking into account all the facts. Whether such compensation should correspond to the market value of the seized property is determined by what is considered to be a fair balance between public and private interests, but in view of the objectives of establishing a much lower value can be considered as imposing an excessive burden on owners. The state's efforts to stimulate economic recovery after the crisis may also be taken into account (McBride, 2020). According to the ECtHR's position, compensation must be reasonably related to the value of the lost property, but does not necessarily correspond to its market value.

The second type of losses that may be incurred by owners during a pandemic is to block the possibility of doing business, which led to a lack of profits. However, as noted, future income in the practice of the ECtHR is considered a kind of property. However, the answer to the question of compensation for such losses is not so clear. According to experts, the inability to use property in business activities can be considered as control over the use if it lasts a short period of time, but can also be considered an interference in the peaceful possession of property in the case of a long period. The question of whether the blocking of shops and restaurants during quarantine will be considered as placing an excessive burden on their owners is very unclear, as in the practice of the ECtHR there are no such situations. The situation can be interpreted as meaning that the closure concerned mainly the control of the activities of potential customers, which may mean that during the period of forced closure there were no legitimate expectations of profit. However, compensation may be required for lost stocks of products that can no longer be used (McBride, 2020). Such approach of the Court - the payment of compensation for the stock, but not the loss of reputation for companies affected by the ban on small arms - can be traced in the case of Andrews v. the United Kingdom (Application № 37657/97).

In Ukraine, in the context of the pandemic and the quarantine imposed in this connection, measures to support business, especially small and medium-sized enterprises, were also introduced by the state. A quarantine support package was approved for entrepreneurs, which included a number of temporary measures, such as tax cuts, cancellation of some payments and lending.

Among the tax preferences are such as exemption from charging and paying for land used in economic activities, real estate tax for residential premises (but only for March), the abolition of fines and penalties for violations of tax laws, the abolition of the single social contribution for individual entrepreneurs, farmers and persons engaged in independent professional activity (but only for two months), moratorium on tax inspections, increase of annual income limits for certain groups of individual entrepreneurs, postponement of filing declarations, postponement of application requirements cash registers, etc. It was also stipulated that if an individual entrepreneur completely ceases his or her activity and does not receive income during this period, he or she is exempt from paying the single tax (Yeshtokin, 2020). 
In addition, in April 2020, the government launched an anti-crisis lending program for micro and small businesses, offering loans at $0 \%$ to repay corporate debt and loans at a rate of $3 \%$ to pay rent, taxes, utilities and salaries. However, analysts note that using this program was quite difficult. According to the survey, most entrepreneurs who needed such loans did not apply for them due to restrictions, and half of those who applied were denied (Kvitsinskaya, 2020).

However, if we analyze the situation in Ukraine during the COVID-19 pandemic, it turns out that the decisions taken are far from ambiguous in terms of ensuring private property rights. First of all, the measures taken to prevent the spread of the disease, which led to restrictions on property rights, did not comply with the principle of legality in the meaning given by the ECtHR and the United Nations guidelines on human rights in the COVID-19 pandemic. The principle of legality means that restrictions on property rights must be introduced strictly by law. The mere fact of a breach of the principle of legality is sufficient to provide protection to owners whose rights have been restricted.

In August 2020, an attempt was made to declare unconstitutional some provisions of the Resolution of the Cabinet of Ministers of Ukraine "On quarantine to prevent the spread of acute respiratory disease COVID-19 caused by coronavirus SARS-CoV-2 and stages of mitigation of countermeasures" of May 20, 2020. These were provisions that prohibited for the period of quarantine, in particular: holding mass events with more than 10 participants; work of public catering establishments, shopping and entertainment centers, activity of establishments providing accommodation services, entertainment establishments, fitness centers, cultural establishments; implementation of regular and irregular transportation of passengers by road in urban, suburban, intercity, intra-regional and inter-regional communication, in particular passenger transportation on city bus routes in the mode of a minibus. That is, the it concerned precisely those provisions which in fact limited the rights of owners to use their property in carrying out business activities, which led to the loss of their income. The decision of the Constitutional Court of Ukraine of August 28, 2020 stated that according to Article 64 of the Constitution of Ukraine, the constitutional rights and freedoms of man and citizen may not be restricted, except in cases provided by the Constitution of Ukraine. In conditions of martial law or state of emergency, certain restrictions on rights and freedoms may be established, indicating the term of these restrictions. At the same time, the Constitutional Court of Ukraine stressed that the restriction of constitutional rights and freedoms of man and citizen is possible only in cases specified by the Constitution of Ukraine. Such a restriction may be established only by law, i.e. by an act adopted by the legislative body in Ukraine. Establishing such a restriction by a bylaw contradicts to Articles 1, 3, 6, 8, 19, 64 of the Constitution of Ukraine.

Thus, in fact, it was recognized that the measures implemented during the quarantine, which led to the restriction of private property rights, can not be considered as consistent with the principle of legality. However, the Constitutional Court of Ukraine with reference to Art. 62 of the Law of Ukraine "On the Constitutional Court of Ukraine" refused to declare the disputed provisions of the above Resolution of the Cabinet of Ministers unconstitutional and closed the constitutional proceedings in this part on the 
grounds that the act (its separate provisions) was repealed. Such an approach deprives the owners of the right to claim compensation for material or moral damage caused to individuals or legal entities by acts and actions that are declared unconstitutional, on the basis of Art. 152 of the Constitution of Ukraine.

However, the owners are not deprived of the right to demand payment of compensation by the state for the deprivation of their property (future income) during the established restrictions. Of course, the consideration of such cases will be ambiguous, and national courts are likely to tend to deny such claims (to protect rights in this case is possible on the basis of Article 1173 of the Civil Code of Ukraine). In addition to the difficulties in substantiating the fact of confiscation of property or causing damage, there is also the question of the qualification of tax preferences and benefits provided, which can be considered as a kind of compensation by the state. Nevertheless, when applying to the ECtHR, there are chances to receive compensation from the Ukrainian state, as potential property income is covered by the concept of property, and there is a violation of the principle of legality.

\section{Conclusions.}

The analysis leads to the conclusion that as a result of the pandemic, all countries faced the same challenges and the measures taken to prevent the consequences of the pandemic were largely similar. However, in some countries, the issue of compensation to owners for quarantine losses has been addressed more effectively, in others less effectively.

What the United States, the United Kingdom, and Ukraine have in common is that the laws of these countries (as in most countries of the world) contain provisions aimed at preventing excessive interference in private property by the state. If such interference occurs in the interests of society or the state, the owners must be compensated. However, the situation that arose during the pandemic is not quite typical, here the rules for preventing state interference in private property are not so obvious to apply. After all, in this case, most often it is not about the seizure of property from private property, but in fact about the prohibition of the use of property in business activities, which entails the loss of future income. Therefore, the question arises whether the owners need to get the compensation of the value of property that is not actually in their possession (future income). However, an analysis of the case law of the ECtHR leads to the conclusion that future income should also be understood as property within the meaning of Protocol №1 to the Convention, and therefore deprivation of business owners of future income can be considered as confiscation of property requiring compensation.

An analysis of the practice of the United States, the United Kingdom, and Ukraine reveals that in all of these countries, there is an understanding that business owners need support in the context of the COVID-19 pandemic. However, the question of the balance of private interest and public interest is resolved in these countries ambiguously. In fact, the amount of compensation paid to owners is not determined by the amount of income 
they lose. Support is provided within the framework of all measures implemented by the state. In fact, not in all countries are these measures sufficient and effective. For example, in Ukraine, the amount of compensation was meager, and it was difficult to take advantage of benefits and credit programs due to bureaucratic procedures. Therefore, it is quite probable that Ukrainian business owners will apply to the court to pay them appropriate compensation for the income lost during quarantine. The analysis leads to the conclusion that in the case of applying for compensation to the national Ukrainian courts, the owners are likely to be denied. In this case, it may be difficult for the owners to justify the seizure of property or damage. In addition, there will be a question about the qualification of tax preferences and benefits provided, which can be considered as a kind of compensation by the state. The situation is complicated by the fact that the Resolution of the Cabinet of Ministers of Ukraine, which introduced quarantine measures, was not declared unconstitutional, despite attempts to recognize it as such. This deprives Ukrainian business owners of the right to claim compensation for material or moral damage caused to them under Art. 152 of the Constitution of Ukraine. However, if Ukrainian owners apply to the ECtHR, they have every chance to receive compensation from the state, because, as we have found, first, potential property income in the practice of the ECtHR is covered by the concept of property. Secondly, since the quarantine measures and related restrictions on the rights of owners were introduced not by law, there is a violation of the principle of legality, which in practice of the ECtHR is one of the main conditions for state intervention in peaceful property. Thus, the violation of the principle of legality gives grounds to demand compensation for interference in the peaceful possession of property.

\section{REFERENCES}

AGUIAR RIBEIRO DO NASCIMENTO, G. (2018). The Long Road to the International Recognition of Economic and Social Rights: The Right to an Adequate Standard of Living. The Age of Human Rights Journal, (11), 43-60. https://doi.org/10.17561/ tahrj.n11.3

ALEXANDRINA, M. (2002). Content of property rights according to modern Russian legislation. $\mathrm{PhD}$ Thesis. Volgograd.

Andrews v. the United Kingdom (Application № 37657/97). [online] Available http://echr. ketse.com/doc/37657.97-en-20000926/

BELYANEVICH, O. (2016). The concept of legitimate expectations and problems of its application by the courts of Ukraine. Private law and entrepreneurship, 16, 41-45.

Council of Europe / European Court of Human Rights. (2019). Handbook under Article 1 of Protocol No. 1 to the Convention for the Protection of Human Rights and Fundamental Freedoms "Protection of Property". [online] Available at: https:// unba.org.ua/publications/4513-posibnik-za-statteyu-1-protokolu-1-do-konvenciipro-zahist-prav-lyudini-ta-osnovopolozhnih-svobod.html 
COVID-19 Control Measures - UK Government Statutory Powers and Summary of Economic/Regulatory Interventions to Date. [online] Available at: https://www. sidley.com/en/insights/newsupdates/2020/03/covid19-control-measures

COVID-19: public law right to compensation when deprived of property. [online] Available at: https://www.sidley.com/en/insights/newsupdates/2020/03/covid19public-law-right-to-compensation-when-deprived-of-property

DEMIR, E. (2017). The Right to Internal Self-Determination in Peacebuilding Processes: A Reinterpretation of the Concept of Local Ownership from a Legal Perspective. The Age of Human Rights Journal, (8), 18-48. https://doi.org/10.1 7561/tahrj.n8.2

Equality and Human Rights Comission. (1998). The Human Rights Act. [online] Available at: https://www.equalityhumanrights.com/en/human-rights/human-rights-act

KARNAUKH, B. (2016). The concept of property in the context of Article 1 of Protocol № 1 to the European Convention for the Protection of Human Rights and Fundamental Freedoms. [online] International law. Philosophy of law. Available at: http://oaji. net/articles/2016/3229-1463726142.pdf.

KVITSINSKAYA, M. (2020). In unequal conditions: how the state (does not) save small business. [online] Available at: https://www.epravda.com.ua/rus/publications/2020 /05/8/660263/

MATTEY, W. \& SUKHANOV, E. (1999). Basic provisions of property rights. Moscow, Jurist.

McBride, J. COVID-19 and Convention. [online] Available at: https://zib.com.ua/ ua/142070-covid-19_i_konvenciya_u_yakiy_miri_borotba_z_koronavirusnoyu. html

MEYER, D. (2003). Russian civil law. Moscow, Statut.

NIYAZOVA, A. (2016). Limits and limitations of land ownership: an analysis of approaches. Perm University Bulletin. Legal sciences, 32, 208-215. https://doi. org/10.17072/1995-4190-2016-32-208-215

POBEDONOSTSEV, K. (2003). Civil law course. Moscow, Zertsalo.

POROTIKOVA, O. (2007). Problems of abuse of subjective civil law. Moscow, Walters Kluver.

Saghinadze and Others v. Georgia (Application 18768/05). [online] Available at: http:// hudoc.echr.coe.int/sites/eng/pages/search.aspx?i=001-98885http://hudoc.echr. coe.int/sites/eng/pages/search.aspx?i=001-98885

SCRIABIN, S. (2006). Ownership and other property rights. Almaty, Jurist.

SHVEDKOVA, O. (2004). Acquisition and implementation of ownership of residential premises. $\mathrm{PhD}$ Thesis. Moscow. 
STIFF, S.M. (2020). COVID-19 response: constitutional protections for private property. [online] Available at: https://crsreports.congress.gov/product/pdf/LSB/ LSB10434

TAGER, E., WHITE, E. \& HAMILTON, L. (2020). Can They Do That? Possible Constitutional Limitations on State Efforts to Require Business-Interruption and Loss-of-Use Carriers to Cover Small Businesses' Losses from COVID-19. [online] Available at: https:/www.mayerbrown.com/en/perspectives-events/ publications/2020/04/can-they-do-that--possible-constitutional-limitations-onstate-efforts-to-require-business-interruption-and-loss-of-use-carriers-to-coversmall-businesses-losses-from-covid19

United Nations. (2020). Emergence measures and COVID-19: Guidance. [online] Available at: https://www.ohchr.org/Documents/Events/EmergencyMeasures_CO VID19.pdf

VEDYAKHIN, V. (1992). Legal incentives: concept, types. Jurisprudence, 1, 51-55.

YESHTOKIN, P. (2020). What measures to support small and medium-sized businesses were introduced in Ukraine during the COVID-19 pandemic. [online] Available at: https://volnovakha.city/read/city/79009/yaki-zahodi-z-pidtrimki-malogo-taserednogo-biznesu-zaprovadili-v-ukraini-pid-chas-pandemii-covid-19

Received: January $16^{\text {th }} 2021$

Accepted: April $5^{\text {th }} 2021$ 